\title{
Modern rural landscapes in contemporary heritage imaginaries: the case of Germany's southern Oderbruch
}

\author{
Emily Bereskin ${ }^{1},{ }^{1}$ \\ ${ }^{1}$ Technical University Berlin, Habitat Unit - Chair of International Urbanism and Design, Berlin, \\ Germany / Université libre de Bruxelles, Faculty of Architecture La Cambre Horta, HABITER \\ study centre, Brussels, Belgium
}

\begin{abstract}
Using the Southern Oderbruch as a case study, this paper investigates the presence and representation of the modern rural landscapes of the German Democratic Republic within the region's contemporary heritage and tourism landscape. Following an analysis of extant discourse production in place marketing materials and heritage sites (primarily local museums), the paper argues that although the unique landscapes developed in concert with the collective farms (landwirtschaftliche Produktionsgenossenschaften) of the GDR remain very much in situ, they remain largely invisible in the heritage and touristic representation of the Oderbruch, which tends to focus on more traditional manifestations of "pastoral beauty" and on historical events preceding the founding of the GDR. This paper hypothesizes several reasons for this conspicuous absence, arguing that the history of the LPG defies local will to narrativise due to its ongoing social, legal, and economic reverberations in everyday life. The second half of the paper reviews the current application effort for a European Cultural Heritage designation for the Oderbruch. The paper highlights the complexity of the situational landscape surrounding the production of heritage, in terms of political, economic, social, and symbolic factors and argues for similar analyses as a comparative path of investigation for the MODSCAPES project.
\end{abstract}

\section{Introduction}

The first line of the MODSCAPES project brochure asks, "Who ever heard of modern rural landscapes?"- a question whose syntax has been chosen carefully to suggest improbability. As we, the members of the MODSCAPES research team, participate in activities designed to bring forward the understanding of "Modernist Rural Landscape" in both academic and public discourse, the posing of this question also signifies a need within our own project to analyse the extent to which modern rural landscapes have already entered into the public consciousness as sites of cultural heritage.

\footnotetext{
${ }^{1}$ Corresponding author: e.bereskin@tu-berlin.de
} 
Are our case studies, and others like them, currently valorised as cultural heritage in any way, shape, or form? If so, by whom and to what end? What are the processes through which heritage values become attributed to these sites? How might the heritagisation process be stymied by the contentious claims made on such sites, both in terms of their historical interpretation and in terms of their present-day repercussions?

As an initial attempt to explore these questions, I examine the case study under investigation by the Technical University's Habitat Unit: the Landwirtschaftliche Produktionsgenossenschaften (agricultural cooperatives for collective production) of the German Democratic Republic (GDR) in the southern Oderbruch, a region approximately $80 \mathrm{~km}$ west of Berlin and $10 \mathrm{~km}$ east of the Polish border. Here, I hope to bring this examination into conversation with other case studies, for I believe that the most significant analysis along this line of questioning will come precisely through comparative inquiry.

The findings presented here are based on an initial analysis of sites of regional historical interpretation, what I refer to as "the heritage landscape." By this, I mean the collection of symbolic markers, both narrative and visual, that serves to designate a site or event as historical, as significant, and to interpret it in a decisive-and selective way. This includes: monuments, museums, signage, tourism guides, and place marketing materials. ${ }^{2}$ These source materials have been augmented by preliminary interviews with local actors involved in heritage production to determine strategies, motivation, and the history of the heritagisation process itself. This research remains ongoing and will be developed further over the course of the upcoming year.

This paper first presents the results of an initial survey examination of regional heritage landscape, showing the types of images and narratives used to present the Oderbruch and analysing the presence of the LPGs in these representations. Overall, the history of the LPGs and the spatial transformation that occurred during the GDR is largely invisible in this heritage landscape, showing up only occasionally as an aside or parenthetical. In the second part of this paper, I pose some hypotheses that might explain this absence, arguing that among local communities there are both structural and psychological factors that may be obstructing the will to narrativise, and that much of the heritagisation work that is being done is currently driven by "outsiders." I conclude by examining a current proposal (still being formulated) to have the Oderbruch designated as a site of European Cultural Heritage and what this process means for local identity creation and the legacy of the GDR.

\section{The LPGs and the rural landscape}

The Oderbruch is a sizeable marshland, which was drained by the Prussian king Friedrich II in the $18^{\text {th }}$ century, an action that turned the formerly uninhabitable area into a liveable, arable landscape. The region was populated by settlers who either crowded into "colonist villages" or lived in individual family farms (Loosegehöfte) that were spread out sparsely across the land [3]. Many of these settlements were destroyed in the final months of World War II by the Soviets who passed through the Oderbruch on their final march into Berlin. After the war, the GDR undertook a massive land reform process to redistribute the land formerly held by the nobility to new settlers and refugees; following

\footnotetext{
${ }^{2}$ My use of the term "heritage landscape" is here conceived as a particular subset of Marc Howard Ross's "symbolic landscape" [1] The subset is based on a collection of aforementioned interpretive "markers" as theorized by Dean MacCannell [2].
} 
the Soviet model, farmland was collectivized as early as the immediate post-war period and was fully collectivized by 1960 [4].

The collective farms constructed during the GDR radically transformed the rural landscape. Trees were felled, boundary lines disappeared, and a landscape characterized by small-scale crop production was reorganized and remade into expansive, often homogeneous fields. The SED planned for the creation of rural settlements to provide social infrastructure to agricultural workers. New housing typologies were built both by the state apparatus as well as by the LPG's Baubrigaden (construction brigades). The SED established and constructed schools, cultural centres, market halls, and other social and cultural institutions that would enhance the quality of life for rural workers. Whether working directly in the field of agriculture or not, the lives of all those living in rural areas were economically, socially, and culturally linked to or affected by the LPG.

Following German reunification, the LPGs were legally dissolved-many closed permanently while others were sold off and became private enterprises. Many social and spatial traces of the LPGs remain: although some structures have been torn down, many larger agricultural structures such as stalls and warehouses are still in use; others stand in varying states of dilapidation. Some have been repurposed with new programs. The houses and social institutions built during the GDR also still remain, although occupation rates vary, and many have had to be repurposed.

\section{Absence in the heritage landscape}

While the LPG remains present in the physical landscape, it is largely absent in the regional imaginary. The most recent, and only widely-distributed guidebook, for the Oderbruch introduces the area as follows:

The region is inextricably linked to two very meaningful events of the $20^{\text {th }}$ century: It was here in the spring of 1945, that the final great battle of the second world war unfolded, and here amongst the floodwaters in 1997, that Germany celebrated unity [6].

In this one sentence, the author highlights two major narrative events of the $20^{\text {th }}$ century-the second world war and the severe flooding of 1997-and casually bypasses the decades of the GDR. Albeit just an anecdotal example from one book, this erasure is echoed across multiple forms of representational markers, regardless of authorship: state organizations, private companies, or community organizations all largely ignore the history of the LPGs in their retelling of local heritage.

Rather, looking at the overall set of regional promotional materials, we see, above all else, a profusion of images showcasing the idyllic, "natural" landscape. Brochures and books are filled with idealized pastoral imagery, often embedded with visitors interacting with the natural environment-fishing, biking, bird-watching, etc. With regard to cultural history and architectural heritage, the emphasis is on Prussian history, with materials promoting cultural sites such as palaces, manor houses, and monasteries. This fixation on unspoilt nature and edifices of the distant past is not particularly surprising as it plays on the most standardized tropes of the tourist gaze, particularly within rural areas.

However, both the academic and commercial understanding of heritage has vastly expanded in the past decades, and today, it is common to see sites related to both industry and modern history modernity within heritage offers, particularly within Germany. Even within this smaller subset of sites, the LPG again does not appear. On 
their website, the region of Brandenburg, which the Oderbruch lies within, promotes 64 sites of industrial heritage, 59 of which are pre-WWII sites, largely involved in production that helped build the city of Berlin during the Industrial Revolution [7].

Within the southern Oderbruch, public history is primarily told through small village employment program immediately following German Reunification. These museums vary greatly in terms of collections, presentation, and upkeep, mostly depending on the amount of resources available and on the personal drive of the employee (usually singular) involved in its creation and maintenance.

One representative example is the Heimatstube Friedrichsaue, which houses a collection of traditional agricultural tools, nearly all of which were collected by one man-now the museum caretaker-over the course of multiple decades. While discussing his collection, he repeatedly exclaimed surprise that people had thrown away these historical tools, leaving them to rot in fields, an exclamation that clearly underlined his personal sense of their value as traditional items. When I asked if he had collected anything from the GDR, he merely waved his hand in a dismissive measure saying that it did not interest him. ${ }^{3}$

$15 \mathrm{~km}$ to the northeast, the Heimatstube Bleyen showcases an assortment of materials donated by village residents, a hodgepodge of items loosely organized into categories such as household, agriculture, and schooling. Objects related to the LPG pop up intermittently, such as a picture of the Konsum displayed above a shelf of GDR food products or a few books on animal husbandry in the library. However, the LPG is not thematised and these items are obscured under by the sheer mass of pre-war material.

A third museum in our case study area, the Filmmuseum Kinder von Golzow is distinct from the others, as it is dedicated not to the history of the village of Golzow, but rather to the presentation of Die Kinder von Golzow, a famous documentary project that tracked the lives of eighteen schoolchildren from 1961, their first day of school in the GDR to 2004, a decade and a half after reunification [8]. The children grew up within the social logic of the LPG, many of whom eventually worked for the LPG or in enterprises supporting it. Historical and political context is given, however, the history of the LPG itself is not strongly thematised, but rather the exhibits focus on the life stories of the children in the documentary and on the history of the documentary itself.

In the first adjoining room to the main exhibition, however, we see one of the only major objects in the region that directly addresses the history of the LPG: a large Wandzeitung ("wall newspaper") written by a local party historian in 1983. This chronicle, displayed across four large boards, recounts the history of Golzow from 1308 to 1983 , but focuses predominately on the history, success, and political importance of the LPG "Einheit" (later renamed, LPG Golzow). For years, the museum curator left it there largely untouched, giving it the appearance of an introduction to the museum, one that foregrounded the LPG as an important historical force in an unquestionable positive light. Recently, a group of students added a sign in the lower corner trying to contextualize the work and present it as a historical artefact of the GDR. The inclusion of this extra marker now makes it read more of a historical artefact of propaganda.

\footnotetext{
${ }^{3}$ Museum Proprietor, Heimatstube Friedrichsaue, Informal conversation with author, May $24^{\text {th }}$, 2018, Friedrichsaue.
} 


\section{Accounting for absence}

How might this absence be explained? Certainly, since reunification, there has been a systematic erasure of East German narratives and symbols; their removal conducted in accordance with the purposeful labelling of the East Germany state as an illegitimate and totalitarian regime [9]. It would be easy to attribute the absence of the LPGs within this framework of contentious symbolic politics; however, based on research conducted thus far, I think such a conclusion would be presumptuous.

I argue instead that what makes this period difficult to narrativise is its ongoing legacy that continues to reverberate into present-day life. Despite their closure almost thirty years ago, the LPGs still exist regionally in a state of suspension, as a prolonged present that has not yet fully experienced historical closure.

Although now privatized and operating under different names, owners, and legal structures, farms of the former collectives do continue to operate in some sense. Many former LPG workers are now unemployed, but others continue to work for the LPGs private successor. As stated, many production buildings built during the GDR continue to be used for agricultural purposes, while others have been repurposed into new businesses and enterprises.

More importantly, legal disputes which began in 1990, concerning property and ownership continue until this day and those disputes that have been settled often remain socially contentious [10]. The process of dissolution and conversion has seen clear winners and losers, resulting in uneven development, social competition, resentment, and conflict. These ongoing social problems may likewise dampen local motivation to narrativise and historicize a past that is still not yet past.

Furthermore, the agricultural industry that succeeded the LPGs has intensified the modernization and industrialization of the landscape in ways that have upset many local residents. These new companies, which rely heavily on automated processes and raise only a limited number of crops (many only for biofuel), are often unpopular with locals, who are extremely vocal in their criticism, blaming these companies for systemic unemployment, soil destruction, and the loss of crop diversity in the region. This end phase of the modernization process itself may be fuelling a desire to uncover precisely those elements of the landscape that were first eradicated by the LPG, that is, the traditional methods of agricultural production and the early settlement structures that existed before the GDR, as seen in the village museums of Friedrichsaue and Bleyen.

\section{Kulturerbe Oderbruch}

The most significant heritage initiative in the region today is arguably the current initiative, Kulturerbe Oderbruch (Cultural Heritage Oderbruch), a group of regional municipalities, foundations, and cultural institutions, which is currently putting together an application to have the area designated as a European Cultural Heritage Landscape [11]. The working group responsible for the application hopes it will spur economic, infrastructural, and social development in the region.

Currently, links between regional municipalities as well as their cultural institutions are rather weak and towns in the Oderbruch operate completely isolated from one another. One of the group's primary aims in pursuit of this designation is to strengthen networks and to create a unifying form of regional identity. In the process, whether purposefully or inadvertently, they are essentially working to create a master narrative for the whole region. 
The narrative they have chosen for the application is the history of the Oderbruch as a modern culture landscape; specifically, they highlight the drainage system of the Oderbruch as a "Landschaftsmaschine (landscape machine)" which they describe as "a system of dikes, pumping stations, trenches, weirs, drainage canals, tidal gates, and measuring stations stretching over an area $60 \mathrm{~km}$ long and 6-12 km wide, a system so complex that it is nearly impossible to fathom" [12] They argue the constant, centurylong battle with a terrain acutely prone to destructive floods produced a unique culture linked to architectural particularities, settlement structures, agricultural practice, and even unique world views, values, and beliefs.

In an interview, one member of the working group explicitly stated that the LPGs and the era of GDR history is undoubtedly part of the history and identity of the region, and that there "have been talks about how to integrate it" into the application; but that as of yet, no decisions have been reached. ${ }^{4}$ Currently, promotional materials produced by the initiative make no specific mention of the LPGs, focusing instead on the technical developments, settlement structures, and agricultural techniques of the $18^{\text {th }}$ and $19^{\text {th }}$ centuries.

The working group aims to submit their application by the end of 2019 , and therefore the bid's final formulation remains to be seen. I would, however, argue that the demands placed upon the application by the EU are at best a challenge, and at worst, a direct obstacle to the serious inclusion of the LPG in any new master narrative. In order to receive the European heritage label, sites must fulfil the following criteria:

Candidate sites for the label must have a symbolic European value and must have played a significant role in the history and culture of Europe and/or the building of the Union. They must therefore demonstrate one or more of the following: (i) their cross-border or pan-European nature: how their past and present influence and attraction go beyond the national borders of a Member State; (ii) their place and role in European history and European integration, and their links with key European events, personalities or movements; (iii) their place and role in the development and promotion of the common values that underpin European integration [13].

By nature, such stipulations constrain and steer discourse production on behalf of producers in order to fulfil these criteria. Indeed, the working group has already implemented the moniker "Klein-Europa (little Europe)" in their promotional materials, such as brochures, postcards, and online media. Citing the historical migratory flows to the region, their brochure Das Oderbruch - Klein Europa Kulturerbe states:

For generations, the people of the Oderbruch have continually welcomed newcomers: Organizing and managing their lives from within, they have developed a sustainable and open political culture, averse to conflict. Cast from this democratic mould, they represent the open future of civil society in rural spaces in Europe [lbid.].

Parallel to the development of critical heritage studies and an increased call for critical reflection in sites of public history, it has become increasingly commonplace in the past two decades to see a critical reflection on heritage production from heritage producers themselves. Heritage producers certainly no longer shy away from working

\footnotetext{
${ }^{4}$ Municipal representative, interview with author, May 30, 2018, Golzow. At the time of writing, the Oderbruch Museum Altranft - Werkstatt für ländliche Kultur, one of the leading institutions involved in the Kulturerbe Oderbruch initiative, was in preparation of their new annual exhibition, this year on the theme of agriculture specifically. It is regrettable that this paper could not take an analysis of this exhibition into consideration; such an analysis is however planned as part of onrnine rocosrnh
} 
with contested sites or "dark heritage," which may have proved more problematic in the 1970s and 1980s. However, reconciling the socialist legacy of forced collectivization with the narratives of European values demanded by the EU will undoubtedly pose a serious challenge as the two appear practically mutually exclusive.

Thus far, the initiative has received considerable support from both the public and private sector; the participating partners showcases the diversity of institutions affected by a such a bid: municipalities, museums, tourism associations, the state ministry of culture, the preservation society, even the state water department. As is to be expected, however, many sceptical and critical parties do exist. Some local institutions view the bid with generalized suspicion, and many local actors are worried about the preservation restrictions that a cultural heritage designation might impose. ${ }^{5}$ And, like any program that necessitates the creation of mutually acceptable and cohesive narratives, it is bound to be contentious.

\section{Conclusions}

Ann-Leena Miller, raised the issue of "dissonant heritage" to contextualize the diversity of responses found among her interviewees [14]. This concept, first developed by Tunbridge and Ashworth in 1996, has proved to be a founding theoretical marker of critical heritage studies [15]. Yet, I would argue that the concept of dissonance is so inherent in heritage production that to speak of it in the context of heritage narratives is almost tautological.

All of the settlements in the MODSCAPES case studies have dissonant narratives, indeed, exceptionally so: whether it is the history of forced collectivization in the GDR and Estonia, colonial rule in Morocco and Libya, fascism in Spain, Italy, and Portugal, or refugee displacements in Greece, the rural landscapes we are investigating stem from highly contentious political circumstances, which, as evidenced by the anthropological investigations of e.g., Kaja Veddel, Martti Veldi, Vittoria Capresi, Marta Prista, and Friedrich Kuhlmann provoke a range of responses, memories, and interpretations $[16,17,18,19]^{6}$.

Our project promises an inquiry into how these modern rural landscapes are, could, or should be considered a form of shared heritage throughout Europe and the Mediterranean, a theme that will surely be central to our final exhibition in 2019. In this pursuit, the first step must be the comparative examination of heritage production and site interpretation thus far: The analysis of existing heritage landscapes reveals critical points of narrative and historical dissonance; it tells us which moments of the past hold meaning in the present as well as which concerns in the present may be dictating the re-imagination of the past [20]. Here, the identification of actors is of utmost importance, as heritage narratives, like all others, are ultimately both products and means of power relations. Only following this line of analysis can we begin our own project of narrative construction, one that will hopefully expand current scholarship and public discourse on modern rural landscapes.

\footnotetext{
${ }^{5}$ Municipal representative, interview with author, May 30, 2018, Golzow

${ }^{6}$ Here I refer to the presentations of the conference panel "Bottom-Up Perspectives on Modernist Realities." There are surely other presentations and cases from the conference that address similar issues.
} 


\section{Acknowledgements}

MODSCAPES is a collaborative research project funded under the HERA - Humanities in the European Research Area 3rd Joint Research Programme dedicated to "Uses of the Past" (20162019). This project has received funding from the European Union's Horizon 2020 research and innovation programme under grant agreement $n^{\circ} 649307$

\section{Brief resume}

Emily Bereskin is currently a postdoctoral fellow at the Habitat Unit, TU of Berlin (she held a similar position at the HABITER Study Center, Faculty of Architecture La Cambre Horta at the Universite libre de Bruxelles at time of participating to the conference). Prior to joining the MODSCAPES team, Dr. Bereskin was a DFG (German Research Foundation) fellow for the international graduate program "The World in the City - Berlin, New York, Toronto" at the Center for Metropolitan Studies, Technische Universität Berlin. She also lectures at Norwich University's Citylab Berlin and the Technische Universität's Master's Programme in Urban Management. Dr. Bereskin received her Ph.D. in Art History from Bryn Mawr College.

\section{References}

1. ROSS, M.H. 2009. Culture and Belonging in Divided Societies: Contestation and Symbolic Landscapes, Philadelphia, University of Pennsylvania Press.

DOI: https://doi.org/10.9783/9780812203509

2. MACCANNELL, D. 1999. The Tourist: A New Theory of the Leisure Class, Berkeley, University of California Press.

3. Das Oderbruch, vols. 1 and 2, 2003. Berlin, Viademica.

4. BAUERKÄMPER, A. 2002. Ländliche Gesellschaft in der kommunistischen Diktatur: Zwangsmodernisierung und Tradition in Brandenburg 1945-1963, Köln, Böhlau Verlag.

5. DIX, A. 2001. "Ländliche Siedlungsplanung in der SBZ und frühen DDR von 1945 bis 1955" in H. Barth (ed.), Grammatik Sozialistischer Architekturen, Berlin, Dietrich Reimer Verlag.

6. WORCH, T. 2014. Oderbruch: Natur und Kultur im östlichen Brandenburg, Trescher Verlag.

7. Industriekultur im Land Brandenburg, Reiseland Brandenburg (n.d.). [Web page]. TMB Tourismus-Marketing Brandenburg. Retrieved from https://www.reiselandbrandenburg.de/aktivitaeten-erlebnisse/kultur/industriekultur/ [available on 10 June 2018].

8. Die Kinder von Golzow: alle Filme 1961-2007. Die älteste Langzeitbeobachtung des internationalen Films. (2010). [Film: 18 DVDs]. Directed by BARBARA AND WINFRIED JUNGE. Berlin, Absolut Medien.

9. LADD, B. (1997) 2008. The Ghosts of Berlin: Confronting German History in the Urban Landscape, Chicago: University of Chicago Press.

DOI: https://doi.org/10.7208/chicago/9780226467603.001.0001

10. BEYERLEIN, A.; KLESMANN, M.; SCHWENKENBECHER J. 2008. "Bauernland in Erbenhand - BGH-Schelte wegen Umgangs mit Bodenreformland Brandenburg will Streitfälle schnell klären”, Berliner Zeitung, $\mathrm{n}^{\circ} 31,6$ February. Rerieved from: https://www.berliner-zeitung.de/bgh-schelte-wegen-umgangs-mit- 
bodenreformland---brandenburg-will-streitfaelle-schnell-klaeren-bauernland-inerbenhand-15552780 [available on 12 January 2019].

11. Kulturerbe Oderbruch (n.d., 2014?). [Web page]. Stiftung Oderbruch. Retrieved from http://stiftung-oderbruch.de/unsere-fonds/spendeninitiativen/kulturerbeoderbruch/ [available on 10 June 2018].

12. MUSEUM ALTRANFT - WERKSTATT FÜR LÄNDLICHE KULTUR. n.d. Das Oderbruch - Klein-Europa Kultureerbe, Brochure, Altranft.

13. EUROPEAN COMMISSION, 2011. Decision No 1194/2011/EU of the European Parliament and of the Council of 16 November 2011 establishing a European Union action for the European Heritage Label. Retrieved from https://eur-lex.europa.eu/legalcontent/EN/TXT/?uri=CELEX:32011D1194\#d1e413-1-1 [available on 10 June 2018].

14. MILLER, A. 2019. "Keep out! No Entry! Exploring the Soviet Military Landscape of the Coast of Estonia", in S. Bell, A. Fisher, V. Capresi et al. (eds.) Modernism, Modernisation and the Rural Landscape, (Proceedings of the MODSCAPES_2018 conference \& Baltic Landscape Forum, Tartu, Estonia, 11-13 June 2018) Les Ulis, EDP Science (SHS Web Conf., $\mathrm{n}^{\circ}$ 63).

DOI: https://doi.org/10.1051/shsconf/20196311001

15. TUNBRIDGE, J. E.; ASHWORTH, G. J. 1996. Dissonant heritage: The management of the Past as a Resource in Conflict, Chichester, John Wiley \& Sons.

16. VEDDEL, K.; VELDI, M. 2019. "Avangard: A Forward-Looking Kolkhoz is Seen as Part of the Past", in S. Bell, A. Fisher, V. Capresi et al. (eds.) Modernism, Modernisation and the Rural Landscape, (Proceedings of the MODSCAPES_2018 conference \& Baltic Landscape Forum, Tartu, Estonia, 11-13 June 2018) Les Ulis, EDP Science (SHS Web Conf., $\mathrm{n}^{\circ} 63$ ).

DOI: https://doi.org/10.1051/shsconf/20196309001

17. CAPRESI, V. 2019. "'We had a Toilet!' The Modernisation of the Countryside as Perceived by the Inhabitants, the Public Spaces and the Presence of Politics in the New Settlements in Italy and Colonial Libya (1932-1939)", in S. Bell, A. Fisher, V. Capresi et al. (eds.) Modernism, Modernisation and the Rural Landscape, (Proceedings of the MODSCAPES_2018 conference \& Baltic Landscape Forum, Tartu, Estonia, 11-13 June 2018) Les Ulis, EDP Science (SHS Web Conf., $\mathrm{n}^{\circ}$ 63). DOI: https://doi.org/10.1051/shsconf/20196309002

18. PRISTA, M. 2019. "The Social Appropriation of the Portuguese Inner Colonisation Project in Boalhosa (1946 -1966)", in S. Bell, A. Fisher, V. Capresi et al. (eds.) Modernism, Modernisation and the Rural Landscape, (Proceedings of the MODSCAPES_2018 conference \& Baltic Landscape Forum, Tartu, Estonia, 11-13 June 2018) Les Ulis, EDP Science (SHS Web Conf., $\mathrm{n}^{\circ} 63$ ).

DOI: https://doi.org/10.1051/shsconf/20196309003

19. KUHLMANN, F.; VELDI, M. 2018. "'Life Was Not All That Bad': Memories and Experiences of Kolkhoz Life in the Baltic States", n S. Bell, A. Fisher, V. Capresi et al. (eds.) Modernism, Modernisation and the Rural Landscape, (Proceedings of the MODSCAPES_2018 conference \& Baltic Landscape Forum, Tartu, Estonia, 11-13 June 2018) Les Ulis, EDP Science (SHS Web Conf., $\mathrm{n}^{\circ}$ 63).

DOI: https://doi.org/10.1051/shsconf/20196309004

20. ROSS, M. H. 2007. Cultural Contestation in Ethnic Conflict, Cambridge: Cambridge University Press.

DOI: https://doi.org/10.1017/cbo9780511491115 